\title{
SEMENTES PARA O (IM)POSSÍVEL
}

Anamaria Ladeira Pereira ${ }^{\mathrm{i}}$

RESENHA: KRENAK, Ailton. Ideias para adiar o fim do mundo. São Paulo: Companhia das Letras, 2019.

Resumo: Publicado meses antes do surgimento da pandemia de coronavírus, o penúltimo livro de Ailton Krenak, Ideias para adiar o fim do mundo, já havia se convertido em leitura obrigatória, devido à originalidade de seus argumentos, embasados em imensa sabedoria ancestral. Neste trágico 2020 e nos próximos, se possíveis, torna-se ainda mais indispensável sua leitura, que denuncia o incomensurável apego a uma ideia fixa de paisagem da Terra e de humanidade como a marca mais profunda do Antropoceno, era da exaustão das fontes de vida que possibilitaram aos seres humanos prosperar. Livro que aduba mentes leitoras, com extremamente necessárias cosmovisões ancestrais, para o crescimento de sementes de solidariedade e justiça social entre os povos.

Palavras chave: ensino; decolonialidade; interculturalidade; movimento indígena; Antropoceno.

\section{SEMILLAS PARA EL (IM)POSIBLE}

Resumen: Publicado meses antes del surgimiento de la pandemia de coronavirus, el penúltimo libro de Ailton Krenak, Ideias para adiar o fim do mundo, ya se había convertido en una lectura obligatoria, debido a la originalidad de sus argumentos, basados en inmensa sabiduría ancestral. De este trágico 2020 en adelante, su lectura se vuelve aún más indispensable, puesto que denuncia el apego inconmensurable a una idea fija del paisaje de la Tierra y la humanidad como la marca más profunda del Antropoceno, período conocido por el agotamiento de las fuentes de vida que permitieron a los seres humanos prosperar. Ese libro fertilizará las mentes con cosmovisiones ancestrales, extremadamente necesarias para el crecimiento de las semillas de solidaridad y justicia social entre los pueblos.

Palabras clave: enseñanza; decolonialidad; educación intercultural; movimiento indígena; Antropoceno.

Precisamente no momento histórico em que o planeta agoniza com tão singular pandemia, um livrosemente pousa nas atônitas mãos de leitoras e leitores, como paraquedas coloridos defendidos pelo semeador e faz brotar muitas interrogações sobre formas de agir que podem aprofundar o caos ou aliviá-lo, em alguma medida. A semente já havia sido lançada, mas somente agora pode-se sentir o germe da esperança, um dos possíveis efeitos da peste global. Nesse contexto de sérias e a cada dia mais desesperadoras ameaças à continuidade da Terra, não como astro do sistema solar, mas como casa da espécie humana, as reflexões reverberadas pelas Ideias para adiar o fim do mundo (2019) têm poder similar ao da água. Escusado seria dizer que tanto os seres que se dizem pensantes quanto o corpo celeste que habitam se compõem, na mesma proporção, dessa imprescindível matéria-prima. Então, como quem abre 
uma janela, em uma casa há muito fechada e cheia de mofo tomando conta da área, faz-se necessário debruçar-se sobre essa obra, diminuta na quantidade de páginas, gigantesca na de sacudidelas, sem meias palavras, cada uma delas inteiramente provida da capacidade de amiudar os olhos de quem a leia e dilatar a mente com brotos para uma ética do cuidado. Ideias não para adiar simplesmente o fim de seus mundos particulares, preservar suas exclusivas existências, no estilo salve-se quem puder. Muito pelo contrário, ideias-sementes para cultivar a urgência de encarar os próprios avessos em busca de preencher ausências nos quesitos compreensão do significado de viver em sociedade e do próprio sentido da experiência da vida. No meio das pedras e quedas e dores que a leitura aprofunda, há imensa leveza, fruto da sabedoria ancestral de seu autor.

Ailton Krenak, pensador e fazedor de outro mundo possível, com título de professor doutor honoris causa pela Universidade Federal de Juiz de Fora, em homenagem ao seu incansável trabalho em defesa da Mãe Terra e de seus filhos e filhas, convocando ações educativas e ambientais pelo mundo, nasceu em território do povo Krenak, na região do Vale do rio Doce. Um professor formado, desde os anos 1970, no incessante combate travado com os que se arrogam a alcunha de donos do poder. Seus diversos enfrentamentos e cobranças ao Estado brasileiro levaram à inclusão de um capítulo relacionado à proteção dos povos indígenas na Constituição de 1988, conquista inédita até então. Na atualidade, como uma das maiores lideranças autóctones, segue na mobilização para que os direitos dos povos originários, com todas as suas especificidades, estejam presentes não apenas nas letras bonitas da Carta Magna. Por meio de um contundente discurso, em 1987, conseguiu que uma emenda constitucional, garantindo os direitos pelos quais lutava, fosse aprovada. Discurso forte como os que integram o exemplar ora resenhado, composto pela transcrição de três palestras suas, a que dá o título ao livro e outras duas: Do sonho e da terra e A humanidade que pensamos ser. Todas ministradas entre 2017 e 2019, trinta anos depois da sua primeira fala pública alcançar notoriedade. Após vários feitos empreendidos, que não incluem somente o uso da voz diante de abismadas plateias, pode-se certificar que a contundência de Ailton Krenak permanece aguçada e ele segue disposto a dar de beber da fonte de seu conhecimento.

Sorte das pessoas que podem escutá-lo ou ler suas provocações inadiáveis sobre como postergar a calamidade. $\mathrm{O}$ autor evidencia, com todas as letras, que não é um pregador do apocalipse e está sempre disposto a contar mais uma história, porque, com elas, o fim do mundo é adiado. Contudo, Krenak questiona o porquê dessas narrativas não entusiasmarem boa parte da humanidade e denuncia como elas "vão sendo esquecidas e apagadas em favor de uma narrativa globalizante, superficial, que quer contar a mesma história para a gente" (KRENAK, 2019, p.10). Qual seria essa tal lenda branca, há séculos, repetida? Essencialmente, a de que a expropriação de terras, o vilipêndio e mesmo o extermínio de culturas constituem parte do preço a se pagar pelo progresso. Estranho que um grupo tão reduzido de pessoas se aposse do lucro completo e todos os outros seres humanos, aqueles que trabalharam de fato para gerar a 
fortuna, tenham de assumir a bruta conta a pagar. Importante atentar para o fato de que esses grupos de pessoas têm cores. Os que brancamente lucram, sabem, como ninguém, fazer do massacre um mal menor ao denominá-lo modernização, sem, no entanto, confessar que a propalada modernidade está manchada por rios de sangue de povos do campo e das florestas propositalmente esquecidos pelo poder público nas periferias e favelas.

Por que a dita civilização resolveu desenraizar as pessoas consideradas não civilizadas de seus lugares de pertencimento, de seus vínculos profundos com a coletividade? De fato, precisavam de mão de obra nos centros urbanos, mas não só isso, há uma motivação bem mais sutil, descrita por Krenak, o que não ameniza, por essa suposta sutileza, seu potencial de destruição. Segundo o ideal escravocrata e colonizador, é imoral o jeito de viver de populações que produzem competências imaginativas baseadas em cosmologias contrárias à noção de acumulação. A humanidade zumbi, nas palavras do autor, à qual os povos originários são intimados a integrar, não admite tanta alegria e fruição, tamanha soberania, por conseguinte, alimenta "uma intolerância muito grande com relação a quem ainda é capaz de experimentar o prazer de estar vivo, de dançar, de cantar. E está cheio de pequenas constelações de gente espalhada pelo mundo que dança, canta, faz chover” (KRENAK, 2019, p.13). A intolerância, motivada pela ganância cruel, leva esses senhores brancos, que acreditam ainda viver na época dos seus antecessores, a pregarem o fim do mundo objetivando a desistência dos sonhos dos povos que jamais vão abrir mão de sonhar, tanto de olhos abertos como fechados, pois para pessoas de diversas culturas, os sonhos trazem caminhos de autoconhecimento para "buscar os cantos, a cura, a inspiração e mesmo a resolução de questões práticas cujas escolhas não se consegue fazer fora do sonho, mas ali estão abertas como possibilidades" (KRENAK, 2019, p.25)

Apesar de toda a potência que as cosmovisões originárias podem compartilhar com as demais, cujas ligações com a sua memória antepassada trazem inenarráveis referências à espoliação e acúmulo egoísta, os estereótipos racistas a respeito dos povos indígenas têm se fortalecido. Há profunda ignorância a respeito da existência de "aproximadamente 250 etnias que querem ser diferentes umas das outras no Brasil, que falam mais de 150 línguas e dialetos" (KRENAK, 2019, p.15). Não são poucas as criaturas que, em vez de pensar ou pesquisar, antes de proferir impropérios, evitam usar o cérebro, esquivam-se dos livros e acusam outras formas de vida de preguiçosas e inúteis. Se o próprio presidente, eleito em 2018 (por mais assombro que isso possa ter gerado e siga gerando), ataca os povos indígenas de múltiplas formas ("nenhum centímetro a mais de terra demarcada"), quem é que não pode também fazê-lo? Através de discursos espúrios, esse presidente deliberadamente autoriza invasões, incêndios e assassinatos de lideranças, pois, segundo suas decisões necropolíticas, que banalizam a vida e incitam o extermínio do que consideram expurgo social, a terra deve ser usada exclusivamente para o crescimento da economia. Os homens que se assenhoram dos rendimentos da mineração, do garimpo, do agronegócio, que ajudaram a eleger tão baixa 
patente entre os fascistas, há dezessete meses ocupando o cargo mais alto do legislativo, costumam agradecer, brindando-o com maior apoio. Como é possível esquecer que há gente por trás disso? Gente com "nome, endereço e até conta bancária, e que conta! São os donos da grana do planeta e ganham mais a cada minuto espalhando shoppings pelo mundo" (KRENAK, 2019, p.11). Nesse combatente livro são escancaradas as lógicas predatórias que têm levado a cabo o desmoronamento do mundo de tantos povos. A ideologia dos ricos, disseminada de variadas formas, obriga os despossuídos a aceitar um sistema genocida de desenvolvimento como modelo de bem-estar. Isso é um retrato do Antropoceno, era da exaustão das fontes de vida provocada pela ganância branca.

Justamente essa humanidade, delatada por Krenak, promove contínuas violações nos direitos humanos, por mais contraditório que seja, pois é dominada por forças coloniais, que sobrevivem até hoje na mentalidade cotidiana de muitos/as brasileiros/as. E é de se perguntar, como o autor questiona: "Por que insistimos tanto e durante tanto tempo em participar desse clube, que na maioria das vezes só limita a nossa capacidade de invenção, criação, existência e liberdade?” (KRENAK, 2019, p.8). Mais além, expõe a mentira entranhada no conceito de sustentabilidade, tão divulgado por autodenominados ambientalistas. “Desenvolvimento sustentável para quê? O que é preciso sustentar?" (KRENAK, 2019, p.12). Como conciliar maneiras tão distintas de ver e sentir o mundo? Para as pessoas que usufruem dos ganhos ou quiseram usufruir, o rio e as montanhas são meros recursos naturais, a partir dos quais riqueza pode ser extraída. Enquanto isso, há milhares de pessoas que consideram o rio um avô e a montanha uma irmã, são as que usufruem da vida, as que ousam vivê-la, não amanhã, mas hoje, não acumulando loucamente para um futuro que pode jamais chegar a acontecer. Sobretudo neste preciso instante, com a explosão mundial da pandemia de coronavírus, o dinheiro armazenado nos cofres dos bancos, em paraísos fiscais ou em forma de imóveis, fazendas, joias e armas pouco ou nada poderá fazer quando os pulmões não conseguirem autonomamente encher-se de ar. O mesmo ar que a Terra dá de graça. Há quem tenha angariado, ao longo dos anos de existência, mais memórias que centavos, menos bens e mais experiências, incontáveis momentos de partilha, apesar de nenhuma reserva do vil metal. "Muitas dessas pessoas não são indivíduos mas 'pessoas-coletivas', células que conseguem transmitir através do tempo suas visões sobre o mundo" (KRENAK, 2019, p.14). Haverá um jeito de encontrar uma possibilidade de contato entre essas diferentes formas de enxergar e experienciar o mundo para que possamos sair desse estado de não reconhecimento uns dos outros? "Esse contato com outra possibilidade implica escutar, sentir, cheirar, inspirar, expirar aquelas camadas do que ficou fora da gente como 'natureza', mas que por alguma razão ainda se confunde com ela”. (KRENAK, 2019, p.33). Em outras eras, tudo o que fizemos foi cair, por que tanto medo agora? Essas e outras indagações as páginas-conversas de Krenak propõem, provocando ideias para deixar no passado essa grave crise. 
Necessário reconhecer que, durante esse período, em que o pânico faz visita em tantos lares ao mesmo tempo, a desigualdade e a injustiça social também dão o tom e deixam em dificuldades infinitamente maiores as pessoas que não possuem renda e acesso à saúde de qualidade, tendo de esperar em longas filas para fazer um simples exame. "Se durante um tempo éramos nós, os povos indígenas, que estávamos ameaçados da ruptura ou da extinção do sentido da nossa vida, hoje estamos todos diante da iminência da Terra não suportar a nossa demanda" (KRENAK, 2020, p.5). Mas essa demanda também é profundamente desigual, enquanto alguns necessitam de uma floresta protegida para produzir alimentos, construir espaços, laços e vivências e desfrutar coletivamente; outros "gastam toda a força da Terra para suprir a sua demanda de mercadorias, segurança e consumo" (KRENAK, 2019, p.25). No rastro da destruição, a indústria do agrotóxico das moralidades também vai matando as sementes da diferença: minorias de gênero e sexualidade, pessoas idosas pobres ou com deficiência, sujeitadas ao ódio cotidiano e institucional.

Ideias para adiar o fim do mundo (2019) conversa perfeitamente com O amanhã não está à venda, lançado neste 2020 catastrófico. Neste último, Krenak nos conta que os povos originários vivem encurralados e refugiados em seu próprio território há muito tempo. "Esse confinamento involuntário nos deu resiliência, nos fez mais resistentes" (KRENAK, 2020, p.4). Ambos os volumes dialogam com a situação atual não apenas brasileira, mas mundial em que, mesmo nesse contexto exasperante, há os que se manifestam favoráveis à abertura do comércio e contrários à quarentena. "Sentimo-nos como se estivéssemos soltos num cosmos vazio de sentido e desresponsabilizados de uma ética que possa ser compartilhada, mas sentimos o peso dessa escolha” (KRENAK, 2019, p.22). Inegável o discernimento que tem acometido parte dos seres humanos de que as escolhas feitas (inclusive o voto no pior candidato possível ou a falta de trabalho de base ou a decisão por uma trajetória extremamente individualista) passam, mais cedo ou mais tarde, a fatura. Há muito tempo, os povos considerados como bárbaros e quase-humanos, já tinham a convicção de que a civilização era um tremendo equívoco e, por isso, "insistem em ficar de fora dessa dança civilizada, da técnica, do controle do planeta. E por dançar uma coreografia estranha, são retirados de cena, por epidemias, pobreza, fome, violência dirigida” (KRENAK, 2019, p.34).

Lançado antes do advento do vírus que, segundo Krenak, discrimina a humanidade porque não estão morrendo outros seres além de humanos, Ideias para adiar o fim do mundo abordou, em seu desfecho, o tema das enfermidades trazidas pelos invasores que dizimaram centenas de povos, ceifando milhares de vidas. Hoje, precisamente hoje, os povos originários estão em perigo, devido à crise no modo de funcionamento da humanidade, que mesmo sem incluí-los nas benesses, exige que a conta seja dividida.

Um sujeito saía da Europa e descia numa praia tropical e largava um rasto de morte por onde passava. $\mathrm{O}$ indivíduo não sabia que era uma peste ambulante, uma guerra bacteriológica em movimento, um fim de mundo; tampouco o sabiam as vítimas 
que eram contaminadas. Para os povos que receberam aquela visita e morreram, o fim do mundo foi no século XVI. (KRENAK, 2019, p.34)

É premente que sejam superadas as incapacidades de estender a visão a lugares para além daqueles em que há um apego pessoal envolvido e onde se vive. Por mais difícil que seja, afastar-se do maior dos confinamentos que reside no esvaziamento da vida, tanto a própria como a alheia. Como sair dessa experiência de maneira diferente? Sem dúvida, abrindo a consciência e começando a desenvolver uma verdadeira preocupação com o que realmente importa, ativando laços de solidariedade entre os povos. Esse é o convite de Ailton Krenak e agora, diante do abismo, resta "aproveitar a nossa capacidade crítica e criativa para construir paraquedas coloridos" (KRENAK, 2019, p.15), baseados nas vivências dos povos originários que, há mais de quinhentos anos, resistem, expandindo suas subjetividades. Contra essa pandemia, como contra todas as outras, que não foram assim nomeadas, pois atingiram parte da humanidade que não é considerada e, sim, vista como descartável, é preciso ter cuidado e coragem. "Coragem para sair de uma atitude de negação da vida para um compromisso com a vida, em qualquer lugar" (KRENAK, 2019, p.24).

\section{Referências:}

KRENAK, Ailton. Ideias para adiar o fim do mundo. São Paulo: Companhia das Letras, 2019.

KRENAK, Ailton. O amanhã não está à venda. São Paulo: Companhia das Letras, 2020.

Recebido em: 30/04/2020.

Aceito em: 05/08/2020.

\section{Notas}

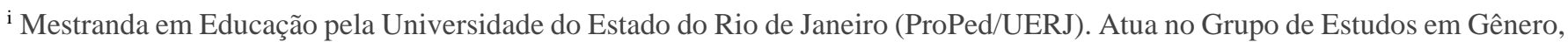
Sexualidade e(m) Interseccionalidades na Educação e(m) Saúde (GENI). Licenciada em Pedagogia pela Universidade Federal do Rio de Janeiro. E-mail: anamariatudojunto@ gmail.com Rio de Janeiro. ORCID: https://orcid.org/0000-0003-1459-3508
} 